\title{
Structure and agency: understanding water policy changes in West Africa
}

\author{
Jan Cherlet ${ }^{\mathrm{a}, \mathrm{b}}$ and Jean-Philippe Venot ${ }^{\mathrm{c}}$ \\ aCorresponding author. Ghent University, Department of Conflict and Development Studies, \\ Universiteitsstraat 8,9000 Ghent, Belgium. E-mail: jan.cherlet@ugent.be \\ 'University of Bologna, Centre for the History of Science and Universities, Via Zamboni 38, 40126 Bologna, Italy \\ Irrigation and Water Engineering Group, Wageningen University, P.O. Box 47, 6700 AA, Wageningen, The Netherlands
}

\begin{abstract}
Ownership of development processes has been high on the international agenda since the Paris Declaration of 2005. There is, however, much discussion about whether highly aid-dependent governments can really 'own' policy reforms in their countries. In this paper, we argue that the ownership of policy reforms is the outcome of an interaction between individual agency and structural conditions. Taking the implementation of Integrated Water Resources Management (IWRM) in Burkina Faso (since 1996) and Mali (since 2004) as an entry point, the paper describes the interplay between national policy makers, international organizations and dominant development discourses in the shaping of water policy reforms in both countries over the past 15 years. Despite the apparent uniformity of the global IWRM paradigm, a qualitative comparison of water policy changes in the two countries shows that policy reforms, as well as the extent to which they are 'owned' by national policy makers, are significantly distinct. This can be explained by different forms of individual agency and diverse structural conditions at a national level.
\end{abstract}

Keywords: Burkina Faso; Integrated Water Resources Management; Mali; Ownership; Policy reform

\section{Glossary}

\begin{tabular}{|c|c|}
\hline $\mathrm{ABFN}$ & Igence du Bassin du Fleuve Niger, Niger River Basin Ag \\
\hline CLE & Comité Local de l'Eau, Local Water Committee \\
\hline DGH & Direction Générale de l'Hydraulique, General Directorate of Hydraulics (in Burkina Faso), later renamed as DGRIH \\
\hline GRE & $\begin{array}{l}\text { Direction Générale des Ressources en Eau, General Directorate of Water Resources (in Burkina Faso), previously } \\
\text { known as DGRIH }\end{array}$ \\
\hline DGRIH & $\begin{array}{l}\text { Direction Générale de l'Inventaire des Ressources en Eau, General Directorate of the Inventory of Water Resources } \\
\text { (in Burkina Faso), previously known as DGH, later renamed as DGRE }\end{array}$ \\
\hline DNACPN & $\begin{array}{l}\text { Direction Nationale de l'Assainissement et du Contrôle des Pollution et des Nuisances, National Directorate of } \\
\text { Sanitation and of Pollution and Nuisance Control (in Mali) }\end{array}$ \\
\hline DNH & Direction Nationale de l'Hydraulique, National Water Directorate (in Mali) \\
\hline GIRENS & $\begin{array}{l}\text { Gestion Intégrée des Ressources en Eau du Niger Supérieur, Integrated Water Resources Management of the Upper } \\
\text { Niger (project in Mali) }\end{array}$ \\
\hline GWP & Global Water Partnership \\
\hline IDWSDD & International Drinking Water and Sanitation Supply Decade \\
\hline IWRA & International Water Resources Association \\
\hline MAHRH & $\begin{array}{l}\text { Ministère de l'Agriculture, de l'Hydraulique et des Ressources Halieutiques, Ministry of Agriculture, Hydraulics and } \\
\text { Fishery Resources (in Burkina Faso) }\end{array}$ \\
\hline NBA & rity (international) \\
\hline NFI & Nordic Freshwater Initiative \\
\hline PAGIRE & $\begin{array}{l}\text { Plan d'Action National de Gestion Intégrée des Ressources en Eau, National Action Plan for Integrated Water } \\
\text { Resources Management }\end{array}$ \\
\hline PAWD & Partnership for Africa's Water Development (project of GWP) \\
\hline PNE-Mali & Partenariat National de l'Eau, National Water Partnership (in Mali) \\
\hline PNIR & $\begin{array}{l}\text { Programme National d'Infrastructures Rurales, National Program for Rural Infrastructure (project of the World } \\
\text { Bank in Mali) }\end{array}$ \\
\hline PROSEA & Programme Sectoriel Eau et Assainissement, Sectoral Program for Water and Sanitation (in Mali) \\
\hline SP-PAGIRE & $\begin{array}{l}\text { Secrétariat Permanent du Plan d'Action pour la Gestion Intégrée des Ressources en Eau, Permanent Secretariat for } \\
\text { the IWRM Action Plan (in Burkina Faso) }\end{array}$ \\
\hline UNCED & United Nations Conference on Environment and Development \\
\hline VREO & $\begin{array}{l}\text { Valorisation des Ressources en Eau de l'Ouest, Development of Water Resources in the West (project in Burkina } \\
\text { Faso) }\end{array}$ \\
\hline WATAC & West African Technical Advisory Committee (to GWP) \\
\hline WWC & World Water Council \\
\hline WWF & er Forum \\
\hline
\end{tabular}




\section{Introduction}

The extent to which donors have implicitly or explicitly used official development assistance to promote donor-aligned policy changes in recipient countries has varied considerably during the history of development aid (Crawford, 2001; Pronk, 2003). The gradual shift from structural adjustment programmes in the 1990s to poverty reduction strategies was presented as a renunciation of donor driven conditionality in favour of local ownership of aid and development. In the 2000s, the ownership agenda was further formalized by the Paris Declaration (2005) and the Accra Agenda for Action (2008) at a global level, and the related Poverty Reduction Strategies or Growth and Sustainable Development Strategies at a national level.

Nevertheless, many scholars have cast doubts on the veracity of the ownership discourse (Whitfield, 2009; Booth, 2011). Whitfield (2009), for example, demonstrated that a government's degree of ownership of reforms and projects correlates with geopolitical and macro-economic conditions, independently from international agreements such as the Paris Declaration. Indeed, the cases adduced by Whitfield show that highly aid-dependent African governments are more likely to write proposals that align with the ideas of donors. Moreover, although most least developed countries (LDCs) have their own national development strategies, donors still have a long way to go to actually align their aid to these plans (Wood et al., 2011). A survey by Clay et al. (2009) confirmed that 'ownership' is indeed perceived differently by different actors; where donors declare their aid as untied, recipient governments still perceive the largest portion of the incoming aid as tied.

In this paper we take the discussion of ownership of policy reforms to a more fundamental level, as we claim that this question can be linked to the century-old quandary of agency versus structure. Comparing water policy reforms in two neighbouring West-African countries, Burkina Faso and Mali, we demonstrate how the dynamics of the reforms and the levels of ownership result from a complex interplay between individual agency (displayed by policy entrepreneurs in the national sphere, as well as in the sphere of the donors and international organizations) and structuring forces (embodied by institutions and dominant development discourses). Our key informants (reported here anonymously) include senior international, Malian and Burkinabé decision makers and practitioners in the water sector.

Integrated Water Resources Management (IWRM) constitutes our entry point for the description of water policy changes in both countries. IWRM is defined by its principal global advocate, the Global Water Partnership (GWP), as 'a process that promotes the coordinated development and management of water, land and related resources, in order to maximize the resultant economic and social welfare in an equitable manner without compromising the sustainability of vital ecosystems' (GWP, 2000a). In practice, the implementation of IWRM supposes a cross-sectoral management of water resources, as well as a vertical integration of different decision-making levels (GWP, 2000a; Conca, 2006). IWRM became the dominant paradigm for water managers worldwide in the early 1990s, when it started being promoted by the United Nations (Conca, 2006). Agenda 21, the influential action plan that was the outcome of the Earth Summit in Rio de Janeiro in 1992, invited all nations in the world to develop national IWRM plans (UN, 1992). This call was repeated in 2002 at the follow-up summit in Johannesburg.

Despite the fact that, today, nearly two-thirds of all countries in the world have national IWRM plans (UN-WATER, 2012), and despite the omnipresence of IWRM in water-related development literature, there is little understanding of how these IWRM plans actually come into being in highly aid-dependent countries. Given the paramount attention to ownership, what is the relative weight of international development actors and of national decision makers in their creation? This paper contributes to filling this gap through a case study of two West-African countries, Burkina Faso and Mali.

Burkina Faso and Mali have had IWRM plans in place since 2003 and 2008, respectively. In both cases, the IWRM-inspired water policy reforms were promoted through high-profile national-level programmes that received financial and technical support from international aid agencies. ${ }^{1}$ However, although the two neighbouring countries evince many systemic similarities (among the 15 least developed countries of the world, heavy reliance on external aid, a large bureaucracy constituting the backbone of public action and authority, and little developed water resources), the water policy reforms are

\footnotetext{
${ }^{1}$ GoBF (2003) estimated that more than $80 \%$ of all investments in the water sector during 1996-2001 were funded by actors other than the national government. In Mali, this percentage amounts to nearly $90 \%$ (DNH, 2008).
} 
characterized by very distinct dynamics, levels of ownership and outcomes. The two countries thus provide for an interesting and complementary inquiry into water policy making in West Africa. The following section provides the analytical framework of the study. We draw from the fields of political science and anthropology of development to shed light on the equilibrium between structure and agency that characterizes the interactions between donors and national policy makers at times of policy change. The third section describes the emergence of IWRM at the international level. In the fourth section we provide a detailed account of the emergence and implementation of IWRM plans in Burkina Faso and Mali. After describing the commonalities and differences between the two cases in the fifth section, the conclusion infers implications for future policy changes in water and natural resources management in African LDCs.

\section{Agency versus structure in development processes}

In accordance with contemporary social thought, we subscribe to individual agency and social structure as being two ontological dimensions that reciprocally constitute each other (King, 2004). Our use of the word 'structure', however, transcends particular theories and corresponds in broad terms to the set of social rules that, imposed upon individuals, ensures social order. In the case of development aid these rules are embedded in institutions (such as bureaucracies), in the politico-economic relations amongst actors (including the donor-recipient relationship), in dominant development discourses, and they are embodied by the individuals themselves as habits and traditions. 'Agency', in turn, refers to the capability of actors to navigate these structuring rules, generate social change despite the structuring rules, and rewrite the rules.

The development literature has agonized over this agency-structure duality, with different schools of thought emphasizing one or the other side of the duality. Political science scholars who give priority to the structural dimensions have shown how, at different points in time, development professionals have framed development problems in different terms. Hence, at different historical moments, the development community have backed different 'blueprint' solutions or 'panacea' (Roberts, 2004; Ostrom et al., 2007; Thorbecke, 2007).

Critical anthropologists of development go a step further and claim that, at any given historical moment, the dominant development discourse encompasses all thinking, and determines which practices are appropriate and which ones unthinkable. Ferguson, for example, believes that the structural power of development discourses even curbs the agency of a global policy maker such as the World Bank: 'the thoughts and actions of 'development' bureaucrats are powerfully shaped by the world of acceptable statements and utterances within which they live' (Ferguson, 2007: 18). This vision from critical anthropology, giving primacy to development discourses in explaining development processes, has informed a critical body of literature in the water sector (e.g. Meinzen-Dick, 2007; Molle, 2008; Barnes, 2009; Gupta, 2009; Ingram, 2011). Gupta, for instance, argues that the continuously shifting discourses in development cooperation have been 'a driving factor in changing [water] policies and policy frameworks in the developing world' (Gupta, 2009: 52), first in promoting large infrastructure works and irrigation schemes, then by experimenting with different forms of local governance and privatization.

At the agency end of the spectrum, political scientists have put forward different theories about the role of individuals and their 'bounded rationality' in triggering or sustaining policy change (Table 1). The 'discourse coalitions' theory (Hajer, 1995) and 'advocacy coalitions' theory (Sabatier \& JenkinsSmith, 1993) describe how individuals and organizations with similar interests and belief systems team up to influence the policy process. Baumgartner \& Jones (1991), who claimed that long periods of gradual policy change are interspersed with short periods of major change, paid tribute in their 'punctuated equilibrium' theory to the role of individuals in triggering these sudden, major policy changes. In Kingdon's (1984) multiple-streams framework, policy change floats on three streams: a problem stream consisting of data and proponents of a policy problem, a policy stream consisting of the solution, and a politics stream propelled by elections and the elected officials. Agile policy entrepreneurs, who can identify and exploit the 'window of opportunity' that appears when the three streams coincide, can generate major policy changes. Atkinson \& Coleman (1989) and Kriesi (1994) have pointed out that policy change depends on a range of actors - not only state or public actors - who work in 
'policy networks'. As network theory emphasizes the mutually interdependency of actors, this theory shifts the focus of attention to the role of relationships rather than to individual actors.

In the field of anthropology as well, the alleged power of dominant development discourses has been deflated by ethnographies that describe how individuals manipulate and negotiate the discourses. In effect, the process of development policy making and implementation, these ethnographies show, is a concatenation of continuous negotiations between different social worlds. Agency appears at any interface where different social worlds interact (Long \& Long, 1992). This agency is embodied by development 'brokers' or 'intermediaries' at these interfaces (Bierschenk et al., 2000; Lewis \& Mosse, 2006). That individuals also play a crucial role in water policy change has been demonstrated many times. Rap (2006) described how the success of a World Bank project to transfer irrigation management to lower levels of decision making in Mexico depended on the intense work of a national, technocratic policy network behind the scene. Huitema \& Meijerink (2009) highlighted the fundamental role of a small number of key water policy entrepreneurs - with very diverse backgrounds - in generating forwardlooking changes in water management in the Netherlands. Drawing on qualitative data concerning radical water policy change in 15 countries worldwide, Huitema et al. (2011) identified five strategies that are commonly harnessed by 'water policy entrepreneurs' and that echo the policy change theories described earlier (see Table 1). The five strategies are: promoting new ideas, building coalitions, recognizing and exploiting windows of opportunity, 'shopping' for various venues (different governmental levels and ministries, media, international networks and forums, multiple donors), and orchestrating a wider network of formal and informal actors involved in the policy domain.

The above literature review shows that structural conditions such as development discourses and institutions condition the behaviour of individual actors. Notwithstanding, individual actors have been able to generate social change on numerous occasions, including in the water sector. Understanding the balance between individual choices and structural determinants, and the relative importance of national and international policy entrepreneurs, appears key to the understanding of how water policy changes come into being: this is what this paper intends to do with regards to IWRM, first at the global level, then in the two neighbouring countries of Burkina Faso and Mali.

Individual strategies

Promoting ideas

Building coalitions

Recognizing and exploiting windows of opportunity Shopping for venues

Orchestrating networks
Underpinning theories of policy change

Punctuated equilibrium (Baumgartner \& Jones, 1991)

Discourse coalitions (Hajer, 1995)

Multiple streams (Kingdon, 1984)

Advocacy coalitions (Sabatier, 1993)

Discourse coalitions(Hajer, 1995)

Policy networks (Atkinson \& Coleman, 1989; Kriesi, 1994)

Multiple streams (Kingdon, 1984)

Punctuated equilibrium (Baumgartner \& Jones, 1991)

Policy networks (Atkinson \& Coleman, 1989; Kriesi, 1994)

Policy networks (Atkinson \& Coleman, 1989; Kriesi, 1994)

Table 1: Individual strategies and related policy change theories (adapted from Huitema et al., 2011)

\section{The emergence of IWRM in the international sphere}

Until the 1990s, international and national donor agencies largely ignored the need for water resources management, as their financial and technical support to the water sector was focused on the provision of drinking water and sanitation (Conca, 2006). Indeed, the first United Nations Water Conference, held in 1977 in Mar del Plata, largely focused on drinking water supply and laid the ground for the International Drinking Water Supply and Sanitation Decade (IDWSSD) in 19801990. Towards the end of the 1980s, uneasiness grew in the community of water professionals and Academics (notably within the International Water Resources Association - IWRA) on the grounds that the cross-sectoral dimension of water was being ignored in most development interventions. Building on their own first-hand experience of IDWSSD projects which were severely limited by their sectoral approach, a number of senior water advisors of the Danish International Development Agency (Danida), which had been an important sponsor of IDWSSD, suggested that Danida establish a Nordic 
Freshwater Initiative (NFI) (KII, 2012a). The NFI had the explicit objective of feeding operational guidelines for integrated water resources planning and management to the forthcoming United Nations Conference on Environment and Development (UNCED) in Rio de Janeiro in 1992 (Jønch-Clausen, 1992). Thanks to two key events - the first Stockholm Water Symposium of 1991 and a subsequent informal consultation with high-level water professionals from multi-lateral agencies in Copenhagen a small cluster of Nordic IWRA professionals, united in the NFI, managed to inject into the Rio process the Copenhagen Statement that advocated two core principles for good water management: (i) water needs to be managed at the 'lowest appropriate' decision-making level; and (ii) it needs to be managed as 'a finite resource with an economic value' (NFI, 1992). The Copenhagen Report is the first document known to use the phrase 'integrated water resources management' (NFI, 1992).

In January 1992, 28 UN agencies and 58 other organizations met in Dublin for the last preparatory meeting before UNCED and agreed on the so-called Dublin Principles, which directly followed from the Copenhagen Statement.

UNCED, a political rather than a technical conference, catapulted IWRM into the global sphere but largely ignored the Dublin Principles. The action plan of UNCED, Agenda 21, was the first inter-governmental policy document to use the phrase 'integrated water resources management' and the acronym IWRM. The document suggested that all states design national IWRM programmes and establish institutional IWRM structures by the year 2000 (UN, 1992).

Danida perceived UNCED to be a major success and renewed its engagement in water-related development for reasons clearly articulated by one of our key informants: 'the Danish government was very happy with the Copenhagen and Dublin Statements and with the impact they had [in Rio], because that is what governments and donors care about: to have a strong footprint. So, Danida got very keen on this IWRM' (KII, 2012a). An earlier presence in Uganda and the involvement of senior Ugandan decision makers in the NFI prompted Danida to choose that country as a pilot case for the development of a national Water Action Plan (1993-1994). The Danish Hydraulic Institute (DHI), a long-standing partner of Danida in water affairs, and whose Water and Environment division was led by the former NFI chair, proved pivotal in the development of this first African IWRM plan.

The vision that UNCED and Agenda 21 constituted a success was not shared by all water professionals, some of whom highlighted, first, the shift away from the more technical approach of the Dublin Principles towards a more developmentalist agenda and, second, the fact that Agenda 21 constituted 'a long list of unreachable and unfundable targets, with no fewer than 184 activities advocated in the [water] chapter alone' (Briscoe \& Garn, 1994: 29). In this context, the Dublin Principles, not Agenda 21, continued to inspire the World Bank, OECD, and the French and Nordic bilateral agencies in water matters (Briscoe \& Garn, 1994). This partly explains why the global call for national IWRM plans did not receive much acclaim. Together, Danida and DHI engaged in replicating the Ugandan experience in Central America (199799) and Burkina Faso (1998-2001), and co-organized a regional IWRM conference with the Burkinabé government (COA-GIRE, in Ouagadougou in 1998), where 11 West-African heads of state marked their commitment to the development of regional and national IWRM plans. At the global level, the institutionalization of IWRM continued with the establishment of a World Water Council (WWC) and a GWP.

The GWP was created upon the initiative of the World Bank, the United Nations Development Programme (UNDP), and the Swedish International Development Agency (Sida) in 1996. It is a global network organization, with branches at regional and national levels, which advocates the implementation of IWRM plans and institutions around the world. Upon its creation, GWP was closely linked to Danida and DHI. The same Danida water professional who had led the NFI became the first chair of the GWP's technical committee, and DHI became GWP's technical secretariat. Also in 1996, the WWC was created, jointly by IWRA and the French utility company Suez-Lyonnaise des Eaux. It is a membership organization for private companies, government and development agencies, whose main activity is the organization of the triennial, highly influential World Water Forum (WWF). This forum is repeatedly used to advance the IWRM agenda at a global level, as was the case in 2000, when GWP presented a Framework for Action that again spurred the world to have "comprehensive policies and strategies for IWRM in process of implementation in $75 \%$ of countries by 2005 and in all countries by 2015' (GWP, 2000b).

IWRM reached its global pinnacle at the World Summit on Sustainable Development, held in Johannesburg 
in 2002, 10 years after Rio. Effective lobbying by Denmark, Sweden and Germany through the European Commission, and by GWP through its well-connected network put IWRM on the Johannesburg agenda (KII, 2011b; KII, 2012a). Governments were urged, once more, to develop national IWRM plans.

The insistent call rallied new organizations and donors in support of IWRM. On the one hand, between 2005 and 2008 the United Nations Environmental Programme (UNEP) implemented the so-called IWRM 2005 Programme to support IWRM planning in over 60 countries and 10 regions of the world. Danida was the main sponsor, and the UNEP-DHI Centre for Water and Environment was in charge of implementation. GWP, on the other hand, attracted sponsorship from the Canadian International Development Agency (Cida) for its new Partnership for Africa's Water Development (PAWD), which aimed to develop IWRM plans in five African countries, including Mali.

\section{Elaborating and implementing IWRM in two West-African countries}

\subsection{Burkina Faso: local expertise and influence in a precursor country}

The first Burkinabé water policy was formulated after the drought of 1973-74 and laid the ground for state-led infrastructure development programmes. It was revised twice during the 1980s but did not change in essence until 1992 (GoBF, 1998; van der Schaaf, 2001), when the structural adjustment programme implied less involvement of the State in most sectors, including water. By the mid-1990s, Burkina Faso was one of the first countries to promote and adopt IWRM principles.

Several concomitant conditions contributed to such a shift. First, there was a growing disenchantment, at national level, with the IDWSSD approach that was focused on infrastructure. Second, the merger in 1995 of the Water Ministry and Environment Ministry brought the issue of water management to the fore, in addition to water development. Third, the international and national water communities were looking for a practical translation to Agenda 21. Fourth, the Burkinabé government and Danida shared an interest in expanding their long-standing cooperation in the water sector (KII, 2012c).

Leaving aside structural explanations, the shift was shouldered by a small team of committed individuals. As one of the key informants stated, '[the reform] boiled down to individuals [...] a small group of people were keen at the idea of change and could defend it vis-à-vis the [minister's] advisors who do not like change much' (KII, 2012c). Alongside this small team of Burkinabé individuals, key members of Danida and DHI were very supportive of the change. Together they engaged in a review of the water sector which led to the formulation (in 1998) of a Water Policy and Strategies document and of the first IWRM programme, and (in 2001) of the water framework law (Loi d'orientation relative à la gestion de l'eau; see Table 2).

The first IWRM programme laid the basis for the development of a National Action Plan for IWRM (PAGIRE) - still with Danida funding. The PAGIRE was approved in 2003 and provided an overarching planning framework for the water sector with a horizon of 2015. A permanent secretariat (the SP-PAGIRE) was set up to monitor and evaluate its implementation.

Concomitantly with the development of the PAGIRE, in 2002 a ministerial reorganization resulted in the creation of a super ministry of Agriculture, Water and Fisheries (the MAHRH) under the authority of an influential minister. A new Director General of the General Directorate of the Inventory of Water Resources (DGRIH, which replaced the DGH and would become the DGRE in 2006) was appointed and proved influential in shaping the next steps of the policy reform. Although new individuals appeared on the stage for the development and implementation phase of the PAGIRE, the few policy entrepreneurs who had initiated the reform process in the mid-1990s remained highly influential. Until 2004, the former Director General of DGH acted as the chair of the West African Technical Advisory Committee (WATAC), a regional satellite of GWP. That one of his close collaborators became the interim director of the Water Resources Coordination Unit of ECOWAS in 2008 further illustrates the influence of Burkinabé policy entrepreneurs at the regional level. Among the other people who drove the reform process in the mid-1990s, one is the current water advisor to the minister for Agriculture and Water, whilst others have become influential consultants, as highlighted by several key informants (KII, 2012d, e). Supported by key policy entrepreneurs, the PAGIRE exerted a strong attraction and other development partners, such as the Sida, started financing the implementation of the programme.

Organizationally speaking, the development and the implementation of Phase 1 of the PAGIRE 
(2003-2008) was characterized by the dominant position assumed by the DGRIH (later the DGRE). This first phase was dominated by a polarized debate as to whether the SP-PAGIRE should continue reporting to the DGRE only, or should be instituted as a transversal organization linking various directorates whilst reporting directly to the Ministry's Secretary General. The latter option, favoured by the donors, won the case, precipitating the departure of the Director General of DGRE. ${ }^{2}$ This first phase centred on institutional building at the national level and on pilot activities in the Nakambé Basin.

Simultaneously, from 2002 onwards, the European Union funded the VREO project (Valorisation des Ressources en Eau de l'Ouest) under the MAHRH. The VREO became the main conduit through which the PAGIRE would be implemented in the west of the country, but not without some friction. Indeed, the VREO was a decentralized project, under the authority of an influential policy entrepreneur and with a separate management team in Bobo-Dioulasso. It was owned by a few individuals who saw the PAGIRE as yet another framework imposed on them from Ouagadougou (KII, 2012f). The VREO team would eventually become the technical wing of the Mouhoun Basin Agency.

Describing the processes of policy formulation at the national level and the interplay between donors and several government departments or ministries only gives a partial picture of the policy process. Local actors (such as policy entrepreneurs, independent consultants and small scale consulting companies) weighed significantly on the shaping of policy, especially regarding the setup of new organizations, such as the Local Water Committees (CLEs) and river basin agencies. In principle, the task of setting up CLEs was the responsibility of the DGRE. The guiding principles, however, had been conceived by a few national consultants - the same individuals who had driven the reform process in the mid-1990s. CLEs were initially devised to manage water at watershed level but they were eventually set up to manage the productive exploitation of well circumscribed water bodies (e.g. irrigated perimeters) - a key objective of the MAHRH. This illustrates how an international water policy model (IWRM) was de facto adjusted to the national priorities of one specific government department. In the case of the CLEs, local consulting companies contracted by the DGRE, or the 'deconcentrated' structures of the MAHRH themselves, had a tremendous impact on the folding out and operation of IWRM.

\subsection{Mali: donor-driven reforms with narrow national ownership}

Between 2000 and 2012 six different ministers and three different ministries have held the water portfolio in Mali. Practical planning and project implementation, however, are carried out by 'directorates', the executive arms of ministries, whose delineations have remained relatively stable over time. The National Hydraulic Directorate (DNH), which reports to the minister in charge of the water portfolio, is responsible for the planning and management of water supply and IWRM projects. Heir of a similar structure from colonial times, the DNH is the main entry point for donors interested in water-related cooperation and has counted a number of permanent western technical advisors in its ranks, virtually since its creation (Matz, 2010). The National Directorate of Sanitation and of Pollution and Nuisance Control (DNACPN), which reports to the minister in charge of environment, has an important secondary role in water supply and sanitation projects but cannot rely on the same technical and managerial experience as the DNH (Danida, 2010).

Until 1991, the predecessor of DNH had sole responsibility for the planning, construction and management of water infrastructure in Mali. Since the adoption of decentralization laws in the mid-1990s, municipalities have been entrusted with the ownership and responsibility of water infrastructure development and management. Concurrently, the technical directorates have also been deconcentrated, with the view of providing technical assistance to the municipalities. Water legislation lagged behind the decentralization laws and, in 1998, the French Development Agency (AFD) in collaboration with UNDP supported the Malian government in the elaboration of a national Water Code (Table 2). Adopted in 2002, the Water Code confirmed the decentralized ownership of water infrastructures and laid the legal foundations for basin agencies and CLEs.

AFD, keen to promote a French-like model of water management, also supported the creation of a Malian Niger River Basin Agency (ABFN) under the direct jurisdiction of the Minister of the Environment

\footnotetext{
${ }^{2}$ The Director General of DGRE joined the African Development Bank in 2008. He argued that the creation of an SPPAGIRE under the authority of the Secretary General was a move in the wrong direction, as it would 'remove the teeth' of a programme already critiqued for its lack of practical outcomes in the field.
} 
in 2002. This move threatened the position of DNH as the main interlocutor of development partners in the water management sector (Matz, 2010). Following a second regional conference on IWRM in Ouagadougou in 2003 (COA-GIRE p 5), and with the support of the World Bank-sponsored National Rural Infrastructure Project (PNIR, 2001-2007), the DNH replicated the AFBN by setting up an IWRM unit themselves (KII, 2012e). The senior hydrologist, who had been acting as the liaison officer for the DNH at the international Niger Basin Authority (NBA) and who was one of the promoters of the IWRM Unit, was appointed at its head. Already known to GWP as the Malian focal point for the elaboration of the West African Water Vision, this person also became the chair of the Malian Country Water Partnership (PNE-Mali), set up by GWP in 2003. Highly regarded by donors (KII, 2012b, d, e), he became the central pivot for IWRM projects in Mali. ABFN, on the contrary, never attracted much support (KII, 2012e).

Between 2004 and 2007, GWP guided Mali through the process of developing a national IWRM plan within the context of its PAWD. It identified DNH and PNE-Mali as lead organizations for the implementation of the PAWD project in Mali. PAWD took off in 2004 with the development of a road map for IWRM planning that was owned by a broad section of water stakeholders, thanks to the involvement of PNE-Mali (Cox \& Patterson, 2008; KII, 2010). After a quick diagnosis of the water sector, this road map yielded a National Water Policy in 2005 and a national IWRM Action Plan (PAGIRE) in 2007.

Although many stakeholders considered the process as more inclusive than that of other projects (especially compared to the World Bank PNIR project), the finalization of the PAGIRE was centralized within the IWRM Unit of DNH (Cox \& Patterson, 2008; KII, 2012e), under the impetus of its director who also chaired PNE-Mali. The double mandate held by this single policy maker also meant that local stakeholders had difficulties in distinguishing PNE-Mali from the governmental IWRM Unit, and it hindered PNE-Mali in playing the role of independent watchdog. The ownership of PAGIRE was eventually limited to a few people in DNH, whose sense of ownership was very high (KII, 2012d, e).

While GWP implemented its PAWD project at policy level, the Dutch government ran an IWRM programme at field level in the Upper Niger Basin (GIRENS, 2004-2010) that engaged in creating basin and sub-basin agencies and CLEs. For historical reasons, the GIRENS programme was not managed by the IWRM Unit of DNH, but by its Hydrology Division. ${ }^{3}$ When the PAGIRE was being developed, the two units competed with one another, mostly because of faltering donor collaboration (KII, 2012e). The rivalry abated towards the end of the PAGIRE process and most of the GIRENS action plan was eventually included in the PAGIRE, as practical recommendations on the development of CLEs and sub-basin agencies.

The PAGIRE plan was officially adopted in April 2008 but implementation was not guaranteed by any donor. However, the aid landscape of Mali's water sector had started changing in 2006 with the arrival of Danida as a new donor. In line with the Paris Declaration, Danida chose to support the embryonic attempt of DNH and DNACPN to develop a Programme for Sectoral Budget Support to Water and Sanitation (PROSEA). Danida supported the creation of an inter-ministerial Cell for Planning and Statistics (CPS) in 2008. This cell has gradually assumed the authority over PROSEA but heavily depends, to date, on Danish technical support. At a donor round-table organized by the head of the IWRM Unit of DNH and the senior technical assistant of GIRENS in February 2009, Danida, Sida and the African Development Bank pledged to support PROSEA. PROSEA finally took off in 2010 and identified the implementation of PAGIRE as one of its four objectives. The programme partly succeeded in aligning the strategies of international development partners and multiple governmental structures.

\footnotetext{
${ }^{3}$ Now called the Division for Water Resources Monitoring and Management.
} 


\begin{tabular}{|c|c|c|c|}
\hline & West Africa (ECOWAS) & Burkina Faso & Mali \\
\hline 1996 & & $\begin{array}{l}\text { Start formulation of the IWRM } \\
\text { program ("Programme GIRE", } \\
\text { agreement with Denmark). }\end{array}$ & \\
\hline 1998 & $\begin{array}{l}\text { West-African IWRM conference, } \\
\text { Ouagadougou } \\
\text { Danida and } \\
\text { (organized bovernment of } \\
\text { Burkina Faso). }\end{array}$ & $\begin{array}{l}\text { Enactment of the Water Policy and } \\
\text { Strategies. }\end{array}$ & $\begin{array}{l}\text { First concertation workshop Water } \\
\text { Code ("Code de l'Eau", initiative } \\
\text { of AFD and UNDP). }\end{array}$ \\
\hline 1999 & $\begin{array}{l}\text { Creation of West-African Technical } \\
\text { Committee of GWP (WATAC). } \\
\text { Creation of SISCOA-GIRE, } \\
\text { regional secretariat to monitor the } \\
\text { implementation of the } 1998 \\
\text { Ouagadougou agreement. }\end{array}$ & $\begin{array}{l}\text { IWRM Program starts (1999-2001, } \\
\text { funded by Danida). } \\
\text { Start of the Nakambè pilot project } \\
\text { (1999-2003, funded by Danida). }\end{array}$ & \\
\hline 2000 & $\begin{array}{l}\text { ECOWAS countries } \\
\text { Regional IWRM plan. }\end{array}$ & & \\
\hline 2001 & & $\begin{array}{l}\text { Adoption of Water Management } \\
\text { Framework Law ("Loi } \\
\text { d'Orientation relative à la Gestion } \\
\text { de l'Eau") }\end{array}$ & $\begin{array}{l}\text { PNIR project starts (2001-2008, } \\
\text { funded by World Bank). }\end{array}$ \\
\hline & & Formulation of PAGIRE starts & \\
\hline 2002 & Creation of GWP West Africa. & $\begin{array}{l}\text { Ministerial reorganization, water is } \\
\text { included in MAHRH ministry; } \\
\text { Environment moves to a separate } \\
\text { ministry. } \\
\text { VREO project starts (2002-2008). }\end{array}$ & $\begin{array}{l}\text { Creation of Malian Niger River } \\
\text { Basin Agency (funded by AFD). } \\
\text { Adoption of Water Code. }\end{array}$ \\
\hline 2003 & $\begin{array}{l}\text { Regional IWRM conference COA- } \\
\text { GIRE+5. }\end{array}$ & $\begin{array}{l}\text { PAGIRE ready and adopted. } \\
\text { PAGIRE Phase } 1 \text { starts. } \\
\text { Creation of SP/PAGIRE for the } \\
\text { monitoring of PAGIRE } \\
\text { implementation. }\end{array}$ & $\begin{array}{l}\text { Creation IWRM Unit at DNH. } \\
\text { Creation PNE-Mali. } \\
\text { GWP, PNE-Mali and DNH sign } \\
\text { PAWD agreement. }\end{array}$ \\
\hline 2004 & $\begin{array}{l}\text { Creation of the WRCU (Water } \\
\text { Resources Coordination Unit) } \\
\text { under the ECOWAS. }\end{array}$ & $\begin{array}{l}\text { Creation of the Water Technical } \\
\text { Committee (cooperation platform). } \\
\text { Start setting up Local Water } \\
\text { Committees (CLE). }\end{array}$ & $\begin{array}{l}\text { GIRENS project starts, creation of } \\
\text { CLEs (2004-2010, funded by the } \\
\text { Netherlands). } \\
\text { Elaboration of PAGIRE starts } \\
\text { (2004-2007, supported by GWP } \\
\text { and CIDA). }\end{array}$ \\
\hline 2006 & & $\begin{array}{l}26 \text { CLEs are set up by the DGRE } \\
\text { (funded by Danida, SIDA, AFD). }\end{array}$ & $\begin{array}{l}\text { National Water Policy adopted (in } \\
\text { the framework of PAWD). }\end{array}$ \\
\hline 2007 & $\begin{array}{l}\text { Creation of Volta Basin Agency } \\
\text { World Bank starts Niger Basin } \\
\text { project, incl. strengthening of } \\
\text { NBA. }\end{array}$ & $\begin{array}{l}\text { Creation of the Nakambé Basin } \\
\text { Agency. }\end{array}$ & PAGIRE ready. \\
\hline 2008 & $\begin{array}{l}\text { IWRM-based Regional Water } \\
\text { Policy }\end{array}$ & & $\begin{array}{l}\text { PAGIRE adopted. } \\
\text { Creation of inter-ministerial CPS } \\
\text { and PROSEA (supported by } \\
\text { Danida). }\end{array}$ \\
\hline 2009 & & $\begin{array}{l}\text { The PAGIRE enters 2nd phase } \\
(2009-2015) .\end{array}$ & $\begin{array}{l}\text { Donor round-table to collect } \\
\text { funding for the PAGIRE } \\
\text { implementation. }\end{array}$ \\
\hline 2010 & & $\begin{array}{l}\text { Expanded SP/PAGIRE put under } \\
\text { the General secretariat of the } \\
\text { MAHRH. } \\
\text { Implementation of PAGIRE in } \\
\text { Mouhoun river basin. Creation of } \\
\text { Mouhoun Basin Agency. }\end{array}$ & $\begin{array}{l}\text { PROSEA (2010-2014) takes off, } \\
\text { incl. implementation of PAGIRE. }\end{array}$ \\
\hline
\end{tabular}

Table 2: Selected steps in the process of water reforms in Burkina Faso and Mali and at the regional level 


\section{Discussion}

\subsection{Structural context}

Policy reforms in Burkina Faso and Mali went through comparable stages. Before the development of a national IWRM action plan started, donors first focused on broad institutional and policy reforms that lasted between 4 and 6 years and which led to the Water Management Framework Law in Burkina Faso (2001) and to the Water Code in Mali (2002). This initial period was also characterized by tentative IWRM activities such as the IWRM Programme in Burkina Faso and GIRENS project in Mali. In a second phase, national IWRM Action Plans (PAGIRE) were developed; this phase lasted 2 years in Burkina Faso (2001-2003) and 4 years in Mali (2004-2007). The third phase, the implementation of the national IWRM action plans, started in 2003 in Burkina Faso and in 2010 in Mali.

Other structural resemblances follow from similar administrative cultures in both countries. First, water policy reforms have been dominated by the technical directorates of the ministry in charge of water (DGRE in Burkina Faso and DNH in Mali), despite a wide participation of national stakeholders in the process. Second, a similar organizational change has taken place in both countries with the PAGIRE now being under the authority of a directorate-independent cell (the SP-PAGIRE in Burkina Faso and the CPS in Mali). This move echoes broader calls for, and support to, a programmatic approach to development aid and marks the recognition of water as a cross-sectoral resource.

One important structural difference stems from the different relations that national governments have with their respective donors. The Burkinabé story shows much more continuity than does the Malian. The reforms in Burkina Faso started in the mid-1990s with funding from Danida, which was already a long-standing donor to the Burkinabé water sector and, since then, has consistently supported the elaboration and implementation of the PAGIRE. In Mali, by contrast, the early donors in water management (AFD, the Netherlands, the World Bank, Cida) adopted a project rather than a sectoral approach and have steered the process of reform according to their own and sometimes conflicting visions of IWRM. While there is currently an attempt to harmonize approaches within the framework of the sectoral PROSEA programme, the director of DNH in Mali still laments that too many foreign consultants are coming in, each of them bringing their own ideas (KII, 2011a). This lack of continuity in Mali's donors was mimicked by frequent ministerial changes, whereas in Burkina Faso one single minister oversaw most of the reform process between 1996 and 2008.

\subsection{The role of individual policy entrepreneurs}

Despite structural similarities, our accounts have shown that individual policy entrepreneurs played a central role at all levels and in all phases. For one thing, IWRM did not become the dominant paradigm worldwide in a disembodied or deterministic fashion. The prominence of the IWRM paradigm in the international sphere is the result of the unrelenting work of a small number of dedicated water professionals and organizations. Using the concepts of Table 1, we can say that a small group of individuals took advantage of the 'window of opportunity' at the end of the IDWSSD decade when a 'problem stream' (the overly sectoral approach of IDWSSD) joined a 'policy stream' (in the form of IWRM) and a 'politics stream' (in the form of the Rio and Johannesburg Conferences). In order to advocate IWRM, they also 'shopped for numerous venues' in the international sphere and 'orchestrated a tight network' of IWRM-inspired organizations including GWP, WWC, IWRA, Danida, DHI, DHI-UNEP, and others.

At a national level, too, the IWRM-inspired reforms were embodied in individual policy entrepreneurs, who assumed different types, forms and levels of engagement, hence yielding distinct reform dynamics and outcomes. The IWRM idea was promoted in West Africa by an 'advocacy coalition' of Danish water professionals flanked by Burkinabé policy makers. As the IWRM idea gained acceptance, a small number of these Burkinabé policy makers, from their key positions in the national water bureaucracy, 'orchestrated a policy network' that made them highly influential both at national and regional level. The head of DGRE played a particularly pivotal role, even though there has been an on-going debate on instituting the SPPAGIRE as a directorate-independent entity. The 'orchestration of the network' was facilitated by the regional and international venues provided for by Danida and later also GWP. By 'shopping for these venues' the Burkinabé network managed to steer the water reforms at regional level (ECOWAS) in a similar direction to that followed in Burkina Faso (KII, 2012c). The Burkinabé IWRM network can count on a large pool of 
competent national consultants (KII, 2012d, e), many of who are former civil servants. These consultants are an integral part of this 'policy network'; they are pivotal in shaping the practice of policy, as they are regularly contracted by governments and regional organizations to draft terms of reference for studies and projects, and for policy implementation guidelines. Such engagement in international forums has not been observed in Mali.

In Mali, the strong appropriation of the IWRM process by the technical DNH directorate was invigorated by organizational rivalries. In 2003, 1 year after AFD had supported the creation of the Malian ABFN, and had linked it to the Minister of Environment, DNH created its own IWRM Unit. This was possible because a few DNH water professionals recognized a window of opportunity when the 'problem stream' (the non-existence of a water resources management unit at DNH) encountered a 'policy stream' (the World Bank PNIR project and the upcoming PAWD project). Another 'window of opportunity' appeared when Danida entered the scene and was willing to sponsor the sectoral budget support programme (PROSEA). The high visibility of the IWRM Unit and its head impeded ABFN from playing any noteworthy role in the water sector.

\subsection{Qualitative differences in ownership}

Water policy reforms need the initiative of policy entrepreneurs. The way in which those entrepreneurs can manifest their agency, however, depends on structural conditions. As these structural conditions influence the strategies of policy entrepreneurs, they also determine the quality of local ownership. This is clearly exemplified by the Burkinabé and Malian cases.

Stable donor support and sufficient human resources in Burkina Faso allowed Burkinabé policy entrepreneurs to join the growing 'IWRM discourse coalition' and to 'orchestrate a policy network' that nowadays extends to the regional and international level. This network is both the expression and warrant of a broad Burkinabé ownership of their water policy reforms. This strong ownership, in exchange, has altered the structural conditions of the Burkinabé reality, such as the relationship with the donors. Malian policy makers, on the contrary, are regularly criticized for not assuming ownership, but for awaiting assistance and for 'accepting all external aid that is being offered' (Bergamaschi, 2009). Our account has showed that this interpretation is too superficial. In a structural context of weak ministerial leadership and highly fragmented sponsorship, a few policy entrepreneurs effectively employed a pro-active strategy of 'drawing together the streams' of donor support and exploited a few 'windows of opportunity' to the maximum. The ownership of water policy reforms in Mali is narrowly vested, but in a very important way, in a small number of water policy makers at DNH and a few long-serving western technical assistants.

Huitema \& Meijerink (2009) argue that the work of policy entrepreneurs is a necessary but not sufficient factor in policy change; this paper would add to this that local policy entrepreneurship is a necessary but not sufficient condition for local ownership. Structural conditions (such as the legacies of the donor-recipient relationship or the quality of national human resources) and the actions of international organizations (for instance, the choice to engage with one policy entrepreneur rather than with another) determine, to a large extent, the way in which policy makers in the aid-receiving country own the policy change.

\section{Conclusion}

The commitment to work towards higher development ownership in the South, made by donors and aid agencies in Paris and Accra, tacitly assumed that aid recipients in the South possessed enough agency to assimilate the 'ownership' of their development (Booth, 2011). This paper engages with this tacit assumption and tries to open up the ownership black box by framing it as the product of an interplay between agency and structure.

To do so, the paper has adduced empirical data from the observation of the emergence of IWRM discourses and policies at the global level and in two Sub-Saharan countries, Burkina Faso and Mali. Although some critics have described IWRM as just another 'nirvana concept' (Molle, 2008) or the 'lingua franca' for water scholars and practitioners (Ingram, 2011), our account shows that this allegedly 'hegemonic paradigm' (Conca, 2006) has been shaped by the relentless work of individuals at global and local level, and has acquired different realities in Burkina Faso and Mali. The differences observed between the two countries are, in the first place, due to differing structural determinants, such as the legacies of earlier donor-recipient collaborations, the attitudes of donors and national policy makers in engaging with each other, and the 
availability of human resources. Within these different structural contexts, water policy makers have also displayed dissimilar forms of agency. In Burkina Faso they mostly engaged in 'orchestrating a broad water policy network' that extends to the regional level, while in Mali they mainly took advantage of 'windows of opportunity' when the international 'policy stream' connected to the national 'problem stream'. This paper concludes that it is structural conditions which largely determine the strategies that policy entrepreneurs can employ to promote and own a policy change. Through their agency, however, policy entrepreneurs try to remodel the structural context and carve out more space for ownership. The form and quality of ownership is the result of this complex interaction between structural conditions and the agency of the policy entrepreneurs.

If donors and aid agencies really want to contribute to an increased ownership of development in the South, they will need to reflect upon the fact that their own actions directly influence the structural conditions, and hence the form and level of ownership a recipient can and will assume.

\section{Acknowledgements}

The authors thank the informants for sharing their knowledge with them. The first author was supported by a doctoral fellowship from the Italian Ministry of Education, Universities and Research (MIUR) and the Special Research Fund (BOF) of Ghent University. The second author conducted this research in the Volta Basin, for the Challenge Programme for Water and Food, a global agricultural research partnership of the Consultative Group on International Agricultural Research (CGIAR); see www.waterandfood.org.

\section{References}

Atkinson, M. \& Coleman, W. D. (1989). Strong states and weak states: sectoral policy networks in advanced capitalist economies. British Journal of Political Science 19(1), 48-67.

Barnes, J. (2009). Managing the waters of Ba'th country: the politics of water scarcity in Syria. Geopolitics 14(3), 510-530.

Baumgartner, F. \& Jones, B. (1991). Agendas and Instability in American Politics. University of Chicago Press, Chicago, IL.

Bergamaschi, I. (2009). Mali: patterns and limits of donor-driven ownership. In: The Politics of Aid: African Strategies for Dealing with Donors. Whitfield, L. (ed.). Oxford University Press, Oxford, UK, pp. 217-245.

Bierschenk, T., Chaveau, J. \& Olivier de Sardan, J. (eds). (2000). Courtiers en développement: Les villages Africaines en quête des projets. Karthala, Paris, France.

Booth, D. (2011). Aid effectiveness: Bringing country ownership (and politics) back in. Working Paper 226. Overseas Development Institute, London, UK. Available at: http://www.odi.org.uk/resources/docs/6028.pdf (accessed 25 January 2013).

Briscoe, J. \& Garn, M. (1994). Financing Agenda 21: Freshwater. A paper prepared for the United Nations Commission on Sustainable Development. Transportation, Water, and Urban Development Department, The World Bank, Washington, DC. Available at: http://www-wds.worldbank.org/external/default/WDSContentServer/WDSP/IB/1994/02/01/000009265_ 3970311114338/Rendered/PDF/multi_page.pdf (accessed 25 January 2013).

Clay, E. J., Geddes, M. \& Natali, L. (2009). Aid Untying: Is it Working? Thematic Study on the Developmental Effectiveness of Untied Aid: Evaluation of the Implementation of the Paris Declaration of the 2001 DAC Recommendation on Untying ODA to the LDCs. Danish Institute for International Studies, Copenhagen, Denmark. Available at: http://www.oecd.org/dac/evaluationnetwork (accessed 25 January 2013).

Conca, K. (2006). Governing Water: Contentious Transnational Politics and Global Institution Building. The MIT Press, Cambridge, MA.

Cox, Ph. \& Patterson, H. (2008). Program Evaluation of Partnership for Africa's Water Development Program (PAWD). CIDA, Quebec, Canada. Available at: http://www.gwp.org/Global/The\%20Challenge/Resource\%20material/final_evalrep_pawd.pdf (accessed 25 January 2013).

Crawford, G. (2001). Foreign Aid and Political Reform. A Comparative Analysis of Democracy Assistance and Political Conditionality. Palgrave, Houndsmills, UK.

Danish International Development Agency (Danida) (2010). Appui Dano-Suédois au Programme Sectoriel Eau et Assainissement (PROSEA), Mali, 2010-2014. Document de programme. Danish Embassy in Mali, Bamako, Mali. Unpublished document.

Direction Nationale de l'Hydraulique (DNH) (2008). Cadre de Dépenses à Moyen Terme 2009-2011. DNH, Bamako, Mali.

Ferguson, J. (2007). The Anti-politics Machine: 'Development', Depoliticisation and Bureaucratic Power in Lesotho. (This edition 2007; originally published 1990). University of Minnesota Press, Minneapolis, MN. 
Gouvernement du Burkina Faso (GoBF) (1998). Politique et stratégies en matière d'eau. GoBF, Ouagadougou, Burkina Faso.

Gouvernement du Burkina Faso (GoBF) (2003). Le PAGIRE dans le contexte du secteur de l'eau du Burkina. Document de base: Table ronde des bailleurs de fonds du plan d'action pour la gestion intégrée des ressources en eau. GoBF, Ouagadougou, Burkina Faso.

Gupta, J. (2009). Driving forces in global freshwater governance. In: Water Policy Entrepreneurs: A Research Companion to Water Transitions Around the Globe. Huitema, D. \& Meijerink, S. (eds). Edward Elgar, Cheltenham, UK, pp. 37-57.

Global Water Partnership (GWP) (2000a). Integrated Water Resources Management. GWP-TAC Background Paper 4. GWP, Stockholm, Sweden. Available at: http://www.gwptoolbox.org/images/stories/gwplibrary/background/tac_4_english.pdf (accessed 25 January 2013).

Global Water Partnership (GWP) (2000b). Towards Water Security: A Framework for Action. GWP, Stockholm, Sweden. Available at: http://www.gwptoolbox.org/images/stories/Docs/water\%20security_2000_doc_78_en.pdf (accessed 25 January 2013).

Hajer, M. A. (1995). The Politics of Environmental Discourse: Ecological Modernization and the Policy Process. Clarendon Press, Oxford, UK.

Huitema, D. \& Meijerink, S. (2009). Policy dynamics in Dutch water management: analysing the contribution of policy entrepreneurs to policy change. In: Water Policy Entrepreneurs: A Research Companion to Water Transitions Around the Globe. Huitema, D. \& Meijerink, S. (eds). Edward Elgar, Cheltenham, pp. 349-368.

Huitema, D., Lebel, L. \& Meijerink, S. (2011). The strategies of policy entrepreneurs in water transitions around the world. Water Policy 13(5), 717-733.

Ingram, H. (2011). Beyond universal remedies for good water governance: a political and contextual approach. In: Water for Food in a Changing World. Garrido, A. \& Ingram, H. (eds). Routledge, London, UK.

Jønch-Clausen, T. (1992). Integrated management of land and water resources at the lowest appropriate levels: the Nordic Freshwater Initiative. In: Water Resources in the Next Century. Proceedings of the Stockholm Water Symposium, 12-15 August 1991, Stockholm. Stockholm Vatten AB, Stockholm, Sweden, pp. 105-118.

King, A. (2004). The Structure of Social Theory. Routledge, New York, NY.

Kingdon, J. (1984). Agendas, Alternatives, and Public Policies. Little, Brown, Boston, MA.

Kriesi, H. (1994). Les démocraties occidentales: Une approche comparée. Economica, Paris, France.

Key Informant Interview (KII) (2010). Interview: 29 September 2010.

Key Informant Interview (KII) (2011a). Interview: 21 August 2011.

Key Informant Interview (KII) (2011b). Interview: 22 August 2011.

Key Informant Interview (KII) (2012a). Interview: 4 January 2012.

Key Informant Interview (KII) (2012b). Interview: 29 February 2012.

Key Informant Interview (KII) (2012c). Interview: 19 April 2012.

Key Informant Interview (KII) (2012d). Interview: 23 April 2012.

Key Informant Interview (KII) (2012e). Interview: 24 April 2012.

Key Informant Interview (KII) (2012f). Email communication: 3 May 2012.

Lewis, D. \& Mosse, D. (2006). Development Brokers and Translators: The Ethnography of Aid and Agencies. Kumarian Press, Bloomfield, CT.

Long, N. \& Long, A. (eds) (1992). Battlefields of Knowledge: The Interlocking of Theory and Practice in Social Research and Development. Routledge, London, UK.

Matz, M. (2010). Rethinking IWRM under cultural considerations. In: Water Politics and Development Cooperation. Scheumann, W., Neubert, S. \& Kipping, M. (eds). Springer-Verlag, Berlin, Germany.

Meinzen-Dick, R. (2007). Beyond panaceas in water institutions. Proceedings of the National Academy for Sciences 104(39), 1520015205 .

Molle, F. (2008). Nirvana concepts, narratives and policy models: insights from the water sector. Water Alternatives 1(1), 131-156.

Nordic Freshwater Initiative (NFI) (1992). Copenhagen Report: Implementation mechanisms for Integrated Water Resources Development and management. Report from Copenhagen informal consultation, November 11-14, 1991. Danida, Copenhagen, Denmark.

Ostrom, E., Janssen, M. A. \& Anderies, J. M. (2007). Going beyond panaceas. Proceedings of the National Academy for Sciences 104(39), 15176-15178.

Pronk, J. P. (2003). Aid as a catalyst: a rejoinder. Development and Change 34(3), 383-400.

Rap, E. (2006). The success of a policy model: irrigation management transfer in Mexico. Journal of Development Studies 42(8), 1301-1324. 
Roberts, J. (2004). Thirty-five years later in development assistance: have we moved on, or just performed a minuet? Development Policy Review 22(5), 483-495.

Sabatier, P. \& Jenkins-Smith, H. (1993). Policy Change and Learning: An Advocacy Coalition Approach. Westview Press, Boulder, CO.

Thorbecke, E. (2007). The evolution of the development doctrine, 1950-2005. In: Advancing Development: Core Themes in Global Economics. Mavrotas, G. \& Shorrocks, A. (eds). Palgrave MacMillan, Houndmills, UK.

United Nations (UN) (1992). Agenda 21: The United Nations Programme of Action from Rio. UN Department of Economic and Social Affairs, Division for Sustainable Development. Available at: http://www.un.org/esa/dsd/agenda21/res_agenda21_18.shtml (accessed 25 January 2013).

UN-WATER (2012). Rio + 20: Water Resource Report. UNESCO Publishing, Geneva, Switzerland.

van der Schaaf, C. (2001). Institutional Change and Irrigation Management in Burkina Faso: Following Structures and Concrete Struggles. ZEF Development Studies 11. Lit-Verlag, Berlin, Germany.

Whitfield, L. (ed.) (2009). The Politics of Aid: African Strategies for Dealing with Donors. Oxford University Press, Oxford, UK.

Wood, B., Betts, J., Etta, F., et al. (2011). The evaluation of the Paris Declaration Phase 2: Final report. Danish Institute for International Studies, Copenhagen, Denmark. Available at: http://pd-website.inforce.dk/content/pdf/PD-EN-web.pdf (accessed 25 January 2013). 